\title{
Optimizing Inorganic Fertilizers Use for Sustainable Intensification of Rain-Fed Maize in Three Agro-Ecological Zones of Mali
}

\section{Traore Lamine ${ }^{1}$, Dicko Mohamed², Kone Mama1, Dioni Lassana1, Diakite Cheick Hamala ${ }^{1}$}

\author{
${ }^{1}$ IER/Sotuba, BP.262, Bamako, Mali \\ ${ }^{2}$ IER, Rue Mohamed V, BP. 258, Bamako, Mali
}

\begin{abstract}
Maize yields on farmers' fields in Mali are usually less than 2 t/ha despite the availability of improved varieties that yield up to $8 \mathrm{t} / \mathrm{ha}$ under optimal management. The low yield is partly due to low soil fertility and lack of site-specific fertilizer recommendations. Studies were carried out in three different agro-ecological zones of Mali, namely the Manding Plateau, Koutiala Plateau and Upper Bani-Niger, to determine the response of maize to different combinations of nitrogen $(\mathrm{N})$, phosphorus $(\mathrm{P})$ and potassium $(\mathrm{K})$ fertilizers. The objective was to determine agronomicaly and economically optimum rates of NPK for use by the smallholder producers in different agroecological zones of Mali. The experimental design was a randomized complete block with three replicates. The treatments were 18 fertilizers rates each subdivided into two subplots for a hybrid maize variety (Tieba) and an open pollinated variety (Sotubaka). A diagnostic treatment including $\mathrm{Zn}, \mathrm{Mg}$, and B was compared with the different levels of NPK to evaluate the effect of trace elements on maize yield and yield components. In terms of grain yields, the best was the diagnostic treatment across the three agro-ecological zones. Increasing application rates to $200 \mathrm{~kg}$ $\mathrm{N} / \mathrm{ha}+80 \mathrm{~kg} \mathrm{P} / \mathrm{ha}$ did not significantly increase grain yields over application of $120 \mathrm{~kg} \mathrm{~N} / \mathrm{ha}+30 \mathrm{~kg} \mathrm{P} / \mathrm{ha}$. Agronomic use efficiency of $\mathrm{N}$ and the value cost ratios (VCR) were negative for all treatments at Kolombada, where rainfall received during the growing season was very low $(567-674 \mathrm{~mm})$ relative to its historic average of $800-1000 \mathrm{~mm}$. The VCR was highest with $90 \mathrm{~kg} / \mathrm{ha} \mathrm{N}+10 \mathrm{~kg} / \mathrm{ha} \mathrm{P}$ at Bougouni and with $30 \mathrm{~kg} / \mathrm{ha} \mathrm{P}$ at Samanko although VCR was less than the cut-off point of 2 in all cases. At Kolombada, fertilizer use was unprofitable regardless of the amount of nutrients applied.
\end{abstract}

Keywords: Agronomic Efficiency, Economic Optimal Rates, Trace Elements, Value Cost Ration

\section{Introduction}

Because of its importance for food security and economic well-being in SSA, maize is considered as life, and is the most important food crop in the region (Sileshi et al., 2011). Maize is mostly grown under rain-fed conditions where precipitation is increasingly becoming erratic in the region (AGRA, (2013). About $40 \%$ of cultivated areas face drought causing yield losses of 10-25\%, CIMMYT, 2013). Despite the availability of improved cultivars and increased use of fertilizers, over the years yields of maize have either stagnated or collapsed in many parts of SSA (Grassini et al., 2013; Ray et al., 2013). Therefore, sustainable intensification of smallholder agriculture is imperative to reduce large food deficits and reverse the current trends of land degradation (Ray et al., 2013; Sanchez, 2010).
Mali is the third largest maize producer in West Africa (FAOSTAT, 2015), and annual production increased from 50,000 tons in 1980 to $1,500,000$ tons in 2010 (DNA, 2012). Much of the increase in production came due to increase in area from 37,000 ha in 1980 to 700,000 ha in 2010 (DNA, 2012). Maize has become the second major crop in terms of production representing $11-25 \%$ of the cereal production, and $17 \%$ of the areas cultivated in Mali. It is a staple food in the semi-arid areas in Mali, mainly grown for human food in various culinary preparations (Kaba Tô, couscous, grilled fresh ears, Biscuit, cake, yoghurt etc.) and animal feed (poultry and livestock). It is also used for the manufacture of synthetic fibers, dyes and plastics. Maize production in Mali is rain-fed and heavily constrained by poor distribution of rainfall. It is also constrained by low

This article is published under the terms of the Creative Commons Attribution License 4.0 Author(s) retain the copyright of this article. Publication rights with Alkhaer Publications.

Published at: http://www.ijsciences.com/pub/issue/2018-04/

DOI: 10.18483/ijSci.1574; Online ISSN: 2305-3925; Print ISSN: 2410-4477 
soil fertility, high input costs and low level of maize processing (Traoré, 2010).

In Mali, as in almost all the arid and semi-arid regions of West Africa, one of the constraints to food security is low soil fertility especially deficiencies in nitrogen (N) and phosphorus (P) (Pieri, 1990). Despite the efforts of the Malian Government to ensure sustainable agriculture, production is still insufficient and limited by poor access to agricultural inputs, particularly fertilizers whose cost remains prohibitive for smallholder farmers (Traoré 2010). Soil depletion is due to nutrient losses estimated at 25 $\mathrm{kg} \mathrm{N}, 3 \mathrm{~kg} \mathrm{P}$ and $20 \mathrm{~kg} \mathrm{~K}$ per year/ha and $2-4 \%$ for organic matter (FAO, 1995). It has been reported that Malian farmers invest $40 \%$ of their annual income in soil fertilization (Niang et al., 2000). Different approaches have been used in the frame work of soil fertility. These include the use of long-term fallows, the association and rotation of crops plus the supply of organic manure (household waste, manure, compost, etc.), but these measures have proved either inadequate or difficult to apply because of multiple technical and socio-economic constraints linked to the production systems (SAFGRAD 1985).

The balanced application of fertilizer inputs is not only important for increasing soil fertility but also an important intervention for tackling the widespread problem of malnutrition. Soil micronutrient deficiencies often translated into low micronutrient contents of crops and subsequently low human dietary intake. For example, low zinc (Zn) and selenium (Se) dietary intake in Uganda and Malawi were associated with low availability of these micronutrients in the soil (Chilimba et al. 2012; Tidemann-Andersen et al. 2011). Application of fertilizer inputs that contain micronutrients to deficient soils is an effective bio-fortification strategy to enhance the grain content of $\mathrm{Zn}$ and $\mathrm{Se}$ (Chilimba et al. 2012).

In spite of the government subsidy program for fertilizer, many poor farmers cannot afford fertilizer use or apply inconsistently at low levels. To overcome this pitfall, optimization of fertilizer use is aimed at maximizing farmer profit from fertilizer use. Although mineral fertilizer use is being promoted as a sustainable intensification pathway, little is known about the nutrient use efficiency and profitability of various fertilizer inputs in Mali. Determining the economics of fertilizer use requires crop nutrient response functions. Therefore, the objectives of this study were to (1) to compare different rates of fertilizers and determine their effect on maize yield and yield components; (2) and determine the economically optimal rates for NPK for the smallholder producers in different agro-ecological zones of Mali. The working hypotheses being tested were (1) varietal differences in maize yield response to NPK fertilizers and profitability vary with agroecological zones particularly with rainfall received during the growing season; (2) combined use of macronutrients (NPK) and micronutrients $(\mathrm{S}+\mathrm{Zn}+\mathrm{B}+\mathrm{Mg})$ significantly increases maize yield over the use of NPK fertilizer alone; and (3) increasing rates of NPK inputs could be unprofitable on sites or seasons with low rainfall.

\section{Material and methods}

The experiments were conducted for two years (2014 and 2015) on three sites in three different agroecological zones of Mali.

\subsection{Site description}

The sites were Samanko on the Mandingue Plateau (annual rain fall 1000-1200 mm), Komlombada on the Koutiala Plateau (rain fall 800-1000 mm) and Bougouni in the Upper Bani-Niger (rainfall > 1200 $\mathrm{mm}$ ) of Mali (Figure 1). The Manding plateau, represented by the Samanko site is an agro-ecological zone characterized by Ferric Lixisols with a gritty texture, an acid reaction and good drainage. The texture of the surface soil is silty, often sandy or loamy. The Koutiala (Kolombada) plateau of is composed of chromic Lixisols characterized by strongly acidic reactions. The texture is normally a sandy loam at the surface and an underground clay loam (PIRT 1986). Bougouni, located in the Upper Bani-Niger agro-ecological zone, is characterized by Plinthosols, with a moderately fine to fine texture. It was developed in silt alluvial streams and characterized by poor drainage and acid reactions. Usually, the texture is fine, loamy on the surface, to become heavier underneath. Like the Koutiala plateau, the increase in the clay content of the soils from the surface is sufficient for an argillic horizon (PIRT 1986). 


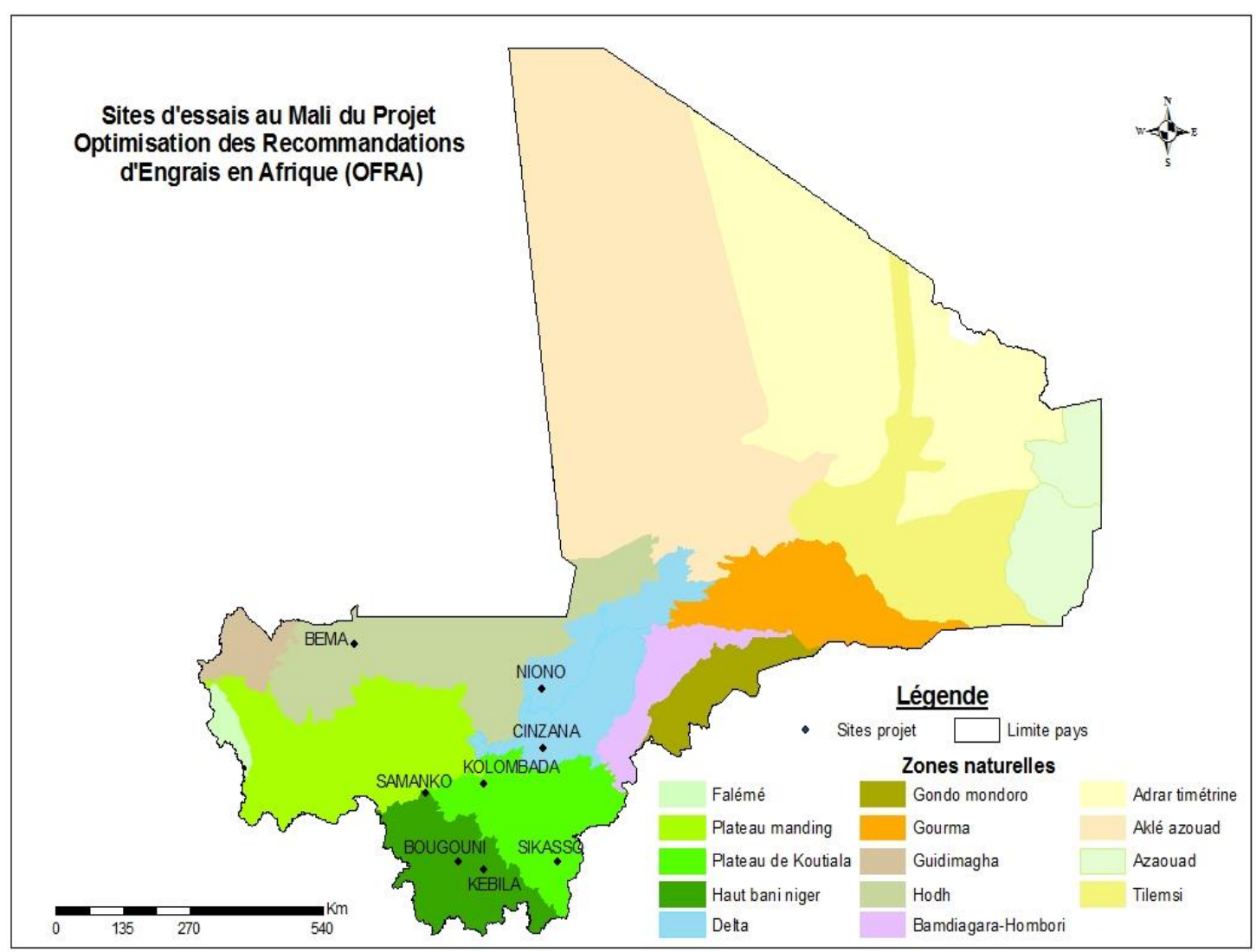

Figure 1: Map of the study sites

All three agro-ecological zones are located in the Sudanian zone. In this zone, the rainfall varies from more than $600 \mathrm{~mm}$ to $1,100 \mathrm{~mm}$. The rainy season is 3-5 months in the north and 5-6 months in the south. Temperatures range from $20^{\circ} \mathrm{C}$ in the dry season and considerably decrease in summer $\left(10^{\circ} \mathrm{C}\right)$, (Soumaré 2014). The average rainfall pattern at Bougouni and Samanko (2014 \& 2015) was characterized by a moderate frequency and intensity of rains with a marked deficit at the beginning of May and June, a fairly good distribution from July to
September and an early termination towards the end of the month which resulted in the premature drying of the plants (Figures 2). The total rainfall received at Bougouni was $1139 \mathrm{~mm}$ in 2014 and $1391 \mathrm{~mm}$ in 2015. At Samanko was $900 \mathrm{~mm}$ in 2014 and $834 \mathrm{~mm}$ in 2015. On the other hand, at Kolombada there was a large rainfall deficit, especially during the 2014 cropping season; the total rainfall received during the 2014 and 2015 cropping seasons being $568 \mathrm{~mm}$ and $634 \mathrm{~mm}$, respectively. 


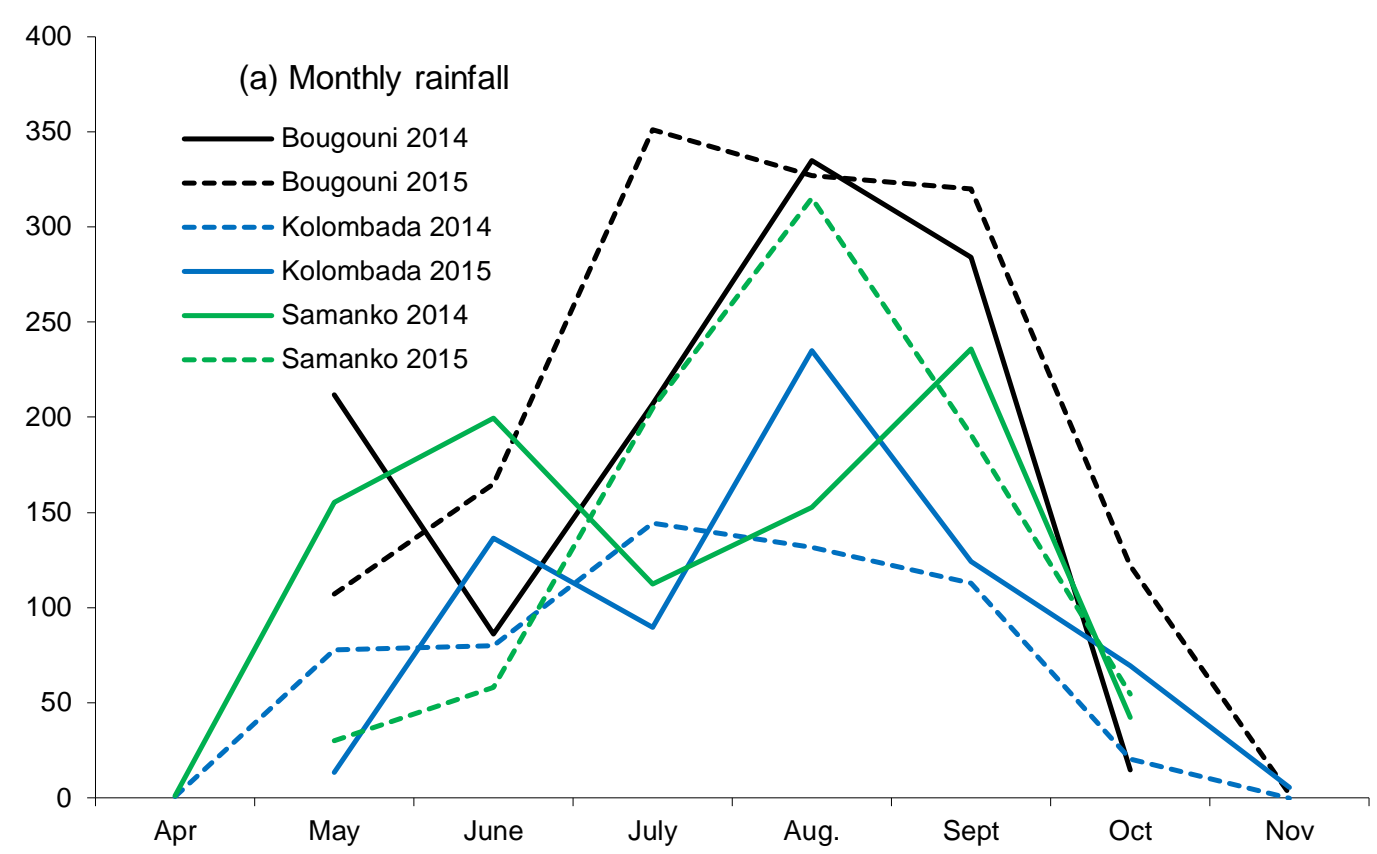

Figure 2: Decade rainfall pattern of Bougouni, Samanko and Kolombada (2 years average)

\subsection{Experimental design and management}

The experimental design was a randomized complete blocks design with 18 treatments subdivided each into two subplots to accommodate two varieties, namely Sotubaka and Tieba. Sotubaka is an open pollinated variety (OPV) of maize, while Tieba is a hybrid maize variety. Sotubaka originated from CIMMYT/IITA. It takes 110-120 days to mature, has yellow grain and a yield potential of 5-6 tons/ha. Tieba originated from IER/IITA, takes 110-115 days, and has white grain and a yield potential of 9-10 tons/ha. The two varieties were chosen because of their high yielding capacity.

The treatments were replicated three times at each site. Each plot was $6 \mathrm{~m} \mathrm{x} 6 \mathrm{~m}\left(36 \mathrm{~m}^{2}\right)$ where 4 lines of Sotubaka and 4 lines of Tieba were planted at 0.80 $\mathrm{m} \times 0.50 \mathrm{~m}$ thinned to 2 plants/hill thus 50000 plants/ha. There was $1 \mathrm{~m}$ space between rows in a bloc, $2 \mathrm{~m}$ space between blocs. The total surface of the trial was $62 \mathrm{~m} \mathrm{x} 43 \mathrm{~m}$ or $2666 \mathrm{~m}^{2}$. Thus the trials were composed of a combination of different rates of $\mathrm{P}(0,10,20,30,40 \mathrm{~kg} / \mathrm{ha})$ and $\mathrm{N}(0,30,60,90,120$ and $200 \mathrm{~kg} / \mathrm{ha}$ ). Since Malian soils are considered to be rich in Potassium $(\mathrm{K})$, crops don't respond significantly to $\mathrm{K}$ application. The following rates of $\mathrm{K}$ were used $(0,10,20,30)$ in the combination of NPK. All the combinations were compared with a diagnostic treatment consisting of the highest rates of $\mathrm{N}(120 \mathrm{~kg} / \mathrm{ha})$ and $\mathrm{P}(80 \mathrm{~kg} / \mathrm{ha})+$ trace elements $(\mathrm{S}$, $\mathrm{Zn}, \mathrm{Mg}, \mathrm{B})$. The diagnostic treatment was included to determine the combined effect of other nutrients once $\mathrm{N}, \mathrm{P}, \mathrm{K}$ is applied. The following codes were used to identify the treatments throughout the manuscript: 1
$=\mathrm{N} 0 \mathrm{P} 0 \mathrm{~K} 0$ (control), $2=\mathrm{NOP} 10 \mathrm{~K} 0,3=\mathrm{N} 0 \mathrm{P} 20 \mathrm{~K} 0,4$ $=$ NOP30K0, $5=$ NOP40K0, $6=$ N90P0K0, $7=$ N90P10K0, $8=$ N90P20K0, $9=$ N90P30K0, $10=$ $\mathrm{N} 30 \mathrm{P} 40 \mathrm{~K} 0,11=\mathrm{N} 30 \mathrm{P} 30 \mathrm{~K} 0,12=\mathrm{N} 60 \mathrm{P} 30 \mathrm{~K} 0,13=$ N120P30K0, 14 = N60P30K10, 15 = N60P30K20, 16 $=$ N60P30K30, $17=$ Diagnostic and $18=$ N200P80K0.

The treatment combinations allowed for at least 4 nutrient levels for the major nutrients. In Mali the fertilizers commonly used are NPK 15-15-15 and diammonium phosphate (DAP) NP 18-46 on cereals and simple super phosphate (SSP) 0-20-0 used on legumes crops. It has been observed that $\mathrm{P}$ is the most yield limiting factor for maize and $\mathrm{N}$ the second factor, but the synergistic effect of both elements was more effective than individual effect. The sources of N, P and K were Urea, Triple superphosphate (TSP), and potassium chloride $(\mathrm{KCl})$, respectively. Magnesium sulfate $\left(\mathrm{MgSO}_{4}, 7 \mathrm{H}_{2} \mathrm{O}\right)$ and Kieserite $\left(\mathrm{MgSO}_{4}, \mathrm{H}_{2} \mathrm{O}\right)$ was used as the source of $\mathrm{Mg}$. Borax $\left(\mathrm{Na}_{2} \mathrm{~B}_{4} \mathrm{O}_{7}, 5 \mathrm{H}_{2} \mathrm{O}\right)$, Zinc sulfate $\left(\mathrm{ZnSO}_{3}, \mathrm{H}_{2} \mathrm{O}\right)$ and calcium carbonate $\left(\mathrm{CaCO}_{3}\right)$ were used as the sources of $\mathrm{B}, \mathrm{Zn}$ and $\mathrm{Ca}$. The $\mathrm{CaCO} 3$ was applied on each treatment in all sites at the rate of $500 \mathrm{~kg} / \mathrm{ha}$ $(\mathrm{pH}<5.2)$. The base fertilizers were applied within 15 days after planting with half Urea and the second rate of Urea was applied 30 days after planting. Weeding was done three times; at 15, 30 and 45 days after sowing.

\subsection{Data collection}

Soil samples were taken each year by the soil - plant -water laboratory of Sotuba Agronomic Research 
Centre for the physico-chemical analysis. The sampling was done before sowing and fertilizers application. In accordance with the OFRA project protocol, site soils were characterized in the same way according to the size and practical arrangement of the experimental design.

Agronomic data on the following variables were collected: Plant number after thinning, day to $50 \%$ flowering, plants number at harvest, harvest ears number, ears weight, \% grain humidity, 1000 grains weight, grain yield (kg/ha), Stover yield (kg/ha) and harvest index. The harvest index is the ratio of grain yield to the total biomass (i.e. Stover + grain yield) and should be $<0.5$. It explains the fertilizer migration in both the grains and in the Stover.

\subsection{Data analysis}

Analysis of variance (ANOVA) was used to determine variation in yield due to the different treatments by site-year and combined across siteyears. In order to avoid the multiplicity problem in multiple comparison tests, the Bonferroni adjustment was made for $\mathrm{P}$ values. It is well-established that with multiple pair-wise comparisons involving a large number of treatments, one will inevitably find something statistically significant (false-positives) due to random variability, even if no real effects exist. This has been called the multiplicity problem. A common practice for addressing this problem has been adjusting the $P$ values using conservative methods such as Bonferroni, Sidak and TukeyCramer or less conservative methods such as Hochberg's methods. In this analysis we applied the Bonferroni procedure.

The next analysis focussed on the effect of $\mathrm{N}$ and $\mathrm{P}$ fertilizer and their interactions. When significant effects of $\mathrm{N}$ rate by $\mathrm{P}$ rate did not occur, asymptotic regression was fitted to the yield data in order to determine response to $\mathrm{N}$. The asymptotic function is given as yield $\left(\mathrm{Mg} \mathrm{ha}^{-1}\right) \mathrm{y}=a-b c^{N}$, where a is yield at the plateau (i.e. expected maximum yield), $b$ is the amplitude (the gain in yield due to nutrient application), $c$ is a curvature coefficient and $N$ is the nutrient rate applied. The regression analysis for $\mathrm{N}$ rate effects included treatments with and without $\mathrm{P}$ separately.

Rain use efficiency (RUE) defined as the ratio of grain yield to seasonal total rainfall was calculated and used as proxy for water use efficiency (WUE). In rain-fed agriculture, WUE is linked to the effectiveness of the use of precipitation because there is no other source of water (Hatfield et al., 2001). In areas where productivity is limited by rainfall, RUE is also shown to account for rainfall variability and to some extent local soil characteristics (Bai et al., 2008). RUE has also been proposed as a robust indicator of productivity and land degradation in moisture-limited areas (Sileshi et al., 2010). Therefore, RUE was used in this study as a metric for evaluating WUE.

Nutrient use efficiency by maize crop was assessed focusing on the agronomic efficiency of $N(A E N)$ at fixed $\mathrm{P}$ rates and agronomic efficiency of $\mathrm{P}$ (AEP) at fixed $\mathrm{N}$ levels. AEN is as an integrated index of fertilizer $\mathrm{N}$ recovery efficiency and physiological $\mathrm{N}$ use efficiency (Ladha et al. 2005). Therefore, it closely reflects impact of the applied $\mathrm{N}$ fertilizer. AEN was calculated as a ratio of the increased crop output to the amount of $\mathrm{N}$ applied. AEP was calculated in the same manner as AEN.

For determining returns to fertilizer use, the valuecost ratio (VCR) was calculated as a ratio of value of increased crop output to the cost of fertilizer applied. VCR measures the average gain in the value of crop output per $\mathrm{kg}$ of fertilizer applied. Technically, VCR $=1$ means that the value of the yield increase over the control equals the cost of the fertilizer and hence the farmer's labour input is not rewarded. If there were no transaction costs in the acquisition of fertilizer, the incentive would be to apply fertilizer to the point where the VCR is 1 . However, there is substantial uncertainty about the outcome of applying fertilizer and transaction costs are inevitable. A VCR $\geq 2$ represents $100 \%$ return on the money invested in fertilizer and is sufficient to warrant investment in fertilizer (Kihara et al. 2016). Therefore, in this analysis $\mathrm{VCR} \geq 2$ was considered as a reasonable threshold for risk coverage against investment in fertilizer at the scale of smallholder farms.

All analysis were done using the Statistix 10 (Analytical Software, Tallahassee, FL).

\section{Results}

\subsection{Initial soil characteristics}

The soils of the experiment sites were clay loam at Bougouni, sandy clay loan at Kolombada and a loamy at Samanko. The soil $\mathrm{pH}$ at Bougouni is below the critical level of 5.6 which is known to limit nutrient availability for crops. Organic carbon and total $\mathrm{N}$ at all sites were below the critical levels of $2 \%$ and $2 \mathrm{~g} \mathrm{~kg}^{-1}$, respectively. The available $\mathrm{P}(27 \mathrm{mg}$ $\mathrm{kg}^{-1}, 18.36 \mathrm{mg} \mathrm{kg}^{-1}$ and $19.5 \mathrm{mg} \mathrm{kg}^{-1}$ ) were above the critical level of $10 \mathrm{mg} \mathrm{kg}^{-1}$. Potassium status of some of the sites was also below the critical value of $0.20 \mathrm{cmol} \mathrm{kg}^{-1}$ (Table 1). A relatively high manganese content was observed at all sites (Table $1)$. 
Table 1. Chemical and physical and characteristics of the soils at the study sites

\begin{tabular}{|c|c|c|c|}
\hline Soil variables & Bougouni & Kolombada & Samanko \\
\hline PH (Eau 1) & 5.4 & 5.7 & 5.6 \\
\hline Organic matter $(\%)$ or carbon $(\%)$ & 0.76 & 0.5 & 0.66 \\
\hline Total N (\%) & 0.03 & 0.02 & 0.03 \\
\hline Available $\mathrm{P}\left(\mathrm{mg} \mathrm{kg}^{-1}\right)$ & 27.0 & 18.36 & 19.5 \\
\hline Sulphur & 11.47 & 7.76 & 8.44 \\
\hline $\mathrm{K}\left(\operatorname{cmol}(+) \mathrm{kg}^{-1}\right)$ & 0.28 & 0.26 & 0.31 \\
\hline $\mathrm{Ca}\left(\operatorname{cmol}(+) \mathrm{kg}^{-1}\right)$ & 2.35 & 2.15 & 2.91 \\
\hline $\operatorname{Mg}\left(\operatorname{cmol}(+) \mathrm{kg}^{-1}\right)$ & 0.68 & 0.84 & 1.16 \\
\hline $\mathrm{Na}\left(\operatorname{cmol}(+) \mathrm{kg}^{-1}\right)$ & 0.10 & 0.09 & 0.11 \\
\hline Bo $\left(\mathrm{mg} \mathrm{kg}^{-1}\right)$ & 0.07 & 0.03 & 0.09 \\
\hline $\operatorname{Mn}\left(\mathrm{mg} \mathrm{kg}^{-1}\right)$ & 77.38 & 65.39 & 66.33 \\
\hline $\mathrm{Zn}\left(\mathrm{mg} \mathrm{kg}^{-1}\right)$ & 1.60 & 0.95 & 1.59 \\
\hline Clay $(\%)$ & 30.0 & 21.5 & 25.0 \\
\hline Silt $(\%)$ & 27.5 & 21.0 & 30.0 \\
\hline Textural Class & Clay Loam & Sandy Clay Loam & Loam \\
\hline Carbon $(\%)$ & 0.43 & 0.28 & 0.39 \\
\hline
\end{tabular}

\subsection{Variation in grain and Stover yield and harvest index}

The combined analysis of variance indicated significant variation in grain yield $(\mathrm{kg} / \mathrm{ha})$, stover yield ( $\mathrm{kg} / \mathrm{ha}$ ) and harvest index with site, variety and treatment (Table 2). Stover yield and harvest index data were not shown in Table 2 to avoid clutter. The main effect of variety was not statistically significant for Bougouni and Kolombada. In addition, the variety by treatment and variety by site by treatment effects were not significant in the combined analysis (Table 2 ). Therefore, the analysis and inferences in the rest of this paper focus on comparing treatments on each site. In terms of grain yields, the best treatment was the diagnostic treatment across the three agroecological zones. At Bougouni the highest grain yield
(5753 kg/ha) was obtained with $120 \mathrm{~kg} \mathrm{~N} / \mathrm{ha}+30 \mathrm{~kg}$ $\mathrm{P} / \mathrm{ha}$, while the lowest yield (3050 kg/ha) was obtained with sole application of $20 \mathrm{~kg} \mathrm{P} / \mathrm{ha}$, which was not significantly different from the control. Increasing application rates to $200 \mathrm{~kg} \mathrm{~N} / \mathrm{ha}+80 \mathrm{~kg}$ $\mathrm{P} /$ ha did not significantly increase grain yields $120 \mathrm{~kg}$ $\mathrm{N} / \mathrm{ha}+30 \mathrm{~kg}$ P/ha.

At Kolombada the highest grain yield (3899 kg/ha) was obtained with $200 \mathrm{~kg} \mathrm{~N} / \mathrm{ha}+80 \mathrm{~kg}$ P/ha, while the lowest yield (1983 kg/ha) was obtained with sole application of $20 \mathrm{~kg}$ P/ha. Similarly, at Samanko the highest grain yield $(6190 \mathrm{~kg} / \mathrm{ha})$ was obtained with $200 \mathrm{~kg} \mathrm{~N} / \mathrm{ha}+80 \mathrm{~kg} \mathrm{P} / \mathrm{ha}$, while the lowest yield $(3761 \mathrm{~kg} / \mathrm{ha}$ ) was obtained with the control (Table 2). 
Optimizing Inorganic Fertilizers Use for Sustainable Intensification of Rain-Fed Maize in Three Agro-Ecological Zones of Mali

Table 2: Site-specific and combined analysis of maize grain yield (kg/ha) response to treatments

\begin{tabular}{|c|c|c|c|c|c|}
\hline 1 & NOP0K0 & $3204.8 \mathrm{~cd}$ & $1983.3 \mathrm{c}$ & $3760.9 \mathrm{c}$ & $2983.0 \mathrm{f}$ \\
\hline 3 & NOP20K0 & $3050.2 \mathrm{~d}$ & $1965.7 \mathrm{c}$ & $4197.4 \mathrm{bc}$ & $3071.1 \mathrm{f}$ \\
\hline 4 & NOP30K0 & $3193.9 \mathrm{~cd}$ & $3394.2 \mathrm{abc}$ & $5215.2 \mathrm{abc}$ & 3934.4 cdef \\
\hline 5 & N0P40K0 & $3622.3 \mathrm{bcd}$ & 1961.7 c & $4374.9 \mathrm{bc}$ & 3319.6 def \\
\hline 7 & N90P10K0 & $4325.8 \mathrm{abcd}$ & $3794.2 \mathrm{ab}$ & $4833.7 \mathrm{abc}$ & $4317.9 \mathrm{abcd}$ \\
\hline 8 & N90P20K0 & $4795.8 \mathrm{abc}$ & $3098.9 \mathrm{abc}$ & $4834.9 \mathrm{abc}$ & 4243.2 abcde \\
\hline 9 & N90P30K0 & $5229.2 \mathrm{ab}$ & $3953.2 \mathrm{a}$ & $5338.5 \mathrm{ab}$ & $4840.3 \mathrm{abc}$ \\
\hline 10 & $\mathrm{~N} 30 \mathrm{P} 40 \mathrm{~K} 0$ & $4666.7 \mathrm{abcd}$ & $3198.9 \mathrm{abc}$ & $4965.5 \mathrm{abc}$ & 4277 abcde \\
\hline 11 & N30P30K0 & $4367.7 \mathrm{abcd}$ & $2990.4 \mathrm{abc}$ & $5238.5 \mathrm{abc}$ & 4198.9 bcde \\
\hline 16 & N60P30K30 & $4467.5 \mathrm{abcd}$ & $3710.9 \mathrm{a}$ & $5077.8 \mathrm{abc}$ & $4418.7 \mathrm{abc}$ \\
\hline 17 & Diagnostic* & 5733.3 a & 3899.6 a & $5358.3 \mathrm{ab}$ & $4997.1 \mathrm{ab}$ \\
\hline \multirow[t]{7}{*}{18} & N200P80K0 & $5709.3 \mathrm{a}$ & $3843.1 \mathrm{ab}$ & $6190 \mathrm{a}$ & 5247.5 a \\
\hline & Site & $N A$ & $N A$ & $N A$ & 0.000 \\
\hline & Variety & 0.544 & 0.546 & 0.001 & 0.017 \\
\hline & Year & 0.009 & 0.485 & 0.000 & 0.227 \\
\hline & $T R T$ & 0.000 & 0.000 & 0.000 & 0.000 \\
\hline & Site $x$ Variety & $N A$ & $N A$ & $N A$ & 0.128 \\
\hline & Site $x$ TRT & $N A$ & $N A$ & $N A$ & 0.044 \\
\hline
\end{tabular}

*Diagnostic treatment consisted of N120P30K20S15Zn2.5Mg10 and B0.5

The response function was estimated for each variety using the average grain yield of two years. The maximum yield response of Sotubaka to $\mathrm{N}$ when $\mathrm{P}$ was applied at a fixed rate of $30 \mathrm{~kg} / \mathrm{ha}$ was achieved at $\mathrm{N}$ rate of 100 and $120 \mathrm{~kg} / \mathrm{ha}$ at Bougouni and Samanko and $90 \mathrm{~kg} / \mathrm{ha} \mathrm{N}$ at Kolombada (Figure 3a). For the hybrid Tieba, the plateau was obtained at 60 $\mathrm{kg} / \mathrm{ha} \mathrm{N}$ at Samanko, $80 \mathrm{~kg} / \mathrm{ha} \mathrm{N}$ at Bougouni and 90 $\mathrm{kg} / \mathrm{ha} \mathrm{N}$ at Kolombada (Figure 3b). At Bougouni the asymptotic $\mathrm{N}$ response function at a fixed $\mathrm{P}$ rate of 30 $\mathrm{kg} / \mathrm{ha}$ was successfully estimated for both Sotubaka and Tieba across two years. The yield plateaus were $5610 \mathrm{~kg} / \mathrm{ha}, 5885 \mathrm{~kg} / \mathrm{ha}$ for Sotubaka and Tieba, respectively. The increases due to fertilizer effect were $2955 \mathrm{~kg} / \mathrm{ha}$ and $2866 \mathrm{~kg} / \mathrm{ha}$, respectively. At Kolombada and Samanko, the asymptotic regression did not fit the data well and the values of $b$ were negative and standards errors were large (Tables 3). 
Optimizing Inorganic Fertilizers Use for Sustainable Intensification of Rain-Fed Maize in Three Agro-Ecological Zones of Mali

Table 3: Coefficients of the asymptotic function for response to $\mathrm{N}$ (at fixed P rate $30 \mathrm{~kg} / \mathrm{ha}$ ), $\mathrm{P}$ (at fixed $\mathrm{N}$ rate of 90 $\mathrm{kg} / \mathrm{ha}$ ), and $\mathrm{K}$ (at fixed $\mathrm{N}$ and P rates of $60 \& 30 \mathrm{~kg} / \mathrm{ha}$ ) for maize varieties Sotubaka and Tieba

\begin{tabular}{|c|c|c|c|c|c|}
\hline Response & Variety & Coefficients & Bougouni & Kolombada & Samanko \\
\hline \multirow{6}{*}{ Response to $\mathrm{N}$} & & $a$ & $5610(238.4)$ & $2948(1717.9)$ & $187422(3.52 \mathrm{E}+08)^{*}$ \\
\hline & Sotubaka & $b$ & 2955 (289.6) & $-46.1(1232.9)^{*}$ & $181903(3.52 \mathrm{E}+08) *$ \\
\hline & & $c$ & $0.97(7.25)^{*}$ & $1.02(0.79)$ & $0.99(0.047)$ \\
\hline & & $a$ & $5885(307.73)$ & $2932(4509.46)^{*}$ & $6784(15236.3)^{*}$ \\
\hline & Tieba & $b$ & $2866(314.47)$ & $113.06(4071.54)^{*}$ & $1608(15128.2)^{*}$ \\
\hline & & $c$ & $0.97(5.55 \mathrm{E}+03)^{*}$ & $1.00(0.17)$ & $0.99(0.033)$ \\
\hline \multirow{6}{*}{ Response to $\mathrm{P}$} & & $a$ & $303550(1.04 \mathrm{E}+09)^{*}$ & $128613(2.67 \mathrm{E}+09)^{*}$ & $30962(231712)^{*}$ \\
\hline & Sotuboka & $b$ & $299216(1.04 \mathrm{E}+09)^{*}$ & $124846(2.67 \mathrm{E}+09)^{*}$ & $25332(231712)^{*}$ \\
\hline & & $c$ & $0.99(0.22)$ & $1.000(1.1549)$ & $1.000(0.1638)$ \\
\hline & & $a$ & $437479(9.96 \mathrm{E}+09)^{*}$ & $160256(2.31 \mathrm{E}+09)^{*}$ & $248057(8.79 \mathrm{E}+09)^{*}$ \\
\hline & Tieba & $b$ & $432799(9.96 \mathrm{E}+09)^{*}$ & $156806(2.31 \mathrm{E}+09)^{*}$ & $243098(8.79 \mathrm{E}+09)^{*}$ \\
\hline & & $c$ & $0.99(0.59)$ & $0.99(0.77)$ & $0.99(0.82)$ \\
\hline \multirow{6}{*}{ Response to $\mathrm{K}$} & & $a$ & $4597(8.79 \mathrm{E}+13)^{*}$ & $3592(8.79 \mathrm{E}+09)^{*}$ & $5921(8.79 \mathrm{E}+09)^{*}$ \\
\hline & Sotubaka & $b$ & $-587(8.79 \mathrm{E}+09)^{*}$ & $1051(8.79 \mathrm{E}+09)^{*}$ & $132.7(8.79 \mathrm{E}+09)^{*}$ \\
\hline & & $c$ & $0.07(0.82)$ & $0.04(0.82)^{*}$ & $0.04(0.06)$ \\
\hline & & $a$ & $4492(101.87)$ & $3493(101.87)$ & $5700(235.16)$ \\
\hline & Tieba & $b$ & $-588(125.63)^{*}$ & $892.6(125.63)$ & $86.82(175.72)$ \\
\hline & & $c$ & $-0.88(0.063)^{*}$ & $-0.02 \quad(0.063 *)$ & $-1.07(0.060)$ \\
\hline
\end{tabular}

Figures in parenthesis are standard errors. Values indicated with * have either implausible estimates or large standard errors and thus are deemed unreliable

The response of Sotubaka to $\mathrm{P}$ (holding $\mathrm{N}$ at 90 $\mathrm{kg} / \mathrm{ha}$ ) had a plateau at $20 \mathrm{~kg} / \mathrm{ha} \mathrm{P}$ at Samanko, at 30 $\mathrm{kg} / \mathrm{ha} \mathrm{P}$ at Bougouni and $14 \mathrm{~kg} / \mathrm{ha} \mathrm{P}$ at Kolombada (Figure 3c). The yield plateau of Tieba was reached at $30 \mathrm{~kg} / \mathrm{ha} \mathrm{P}$ at Samanko and Bougouni, while at Kolombada the plateau was reached at $20 \mathrm{~kg} / \mathrm{ha} \mathrm{P}$ (Figure 3d).
The response of Sotubaka to $\mathrm{K}$ when $\mathrm{N}$ and $\mathrm{P}$ were applied at $60 \mathrm{~kg} / \mathrm{ha} \mathrm{N}$ and $30 \mathrm{~kg} / \mathrm{ha} \mathrm{P}$ had a plateau at $20 \mathrm{~kg} / \mathrm{ha} \mathrm{K}$ at Samanko and Bougouni after which point the effect of $\mathrm{K}$ becomes negative (Figure 3e). The plateau for Tieba was observed at $20 \mathrm{~kg} / \mathrm{ha} \mathrm{K}$ at Samanko, Bougouni and Kolombada (Figure 3f). 
Optimizing Inorganic Fertilizers Use for Sustainable Intensification of Rain-Fed Maize in Three Agro-Ecological Zones of Mali
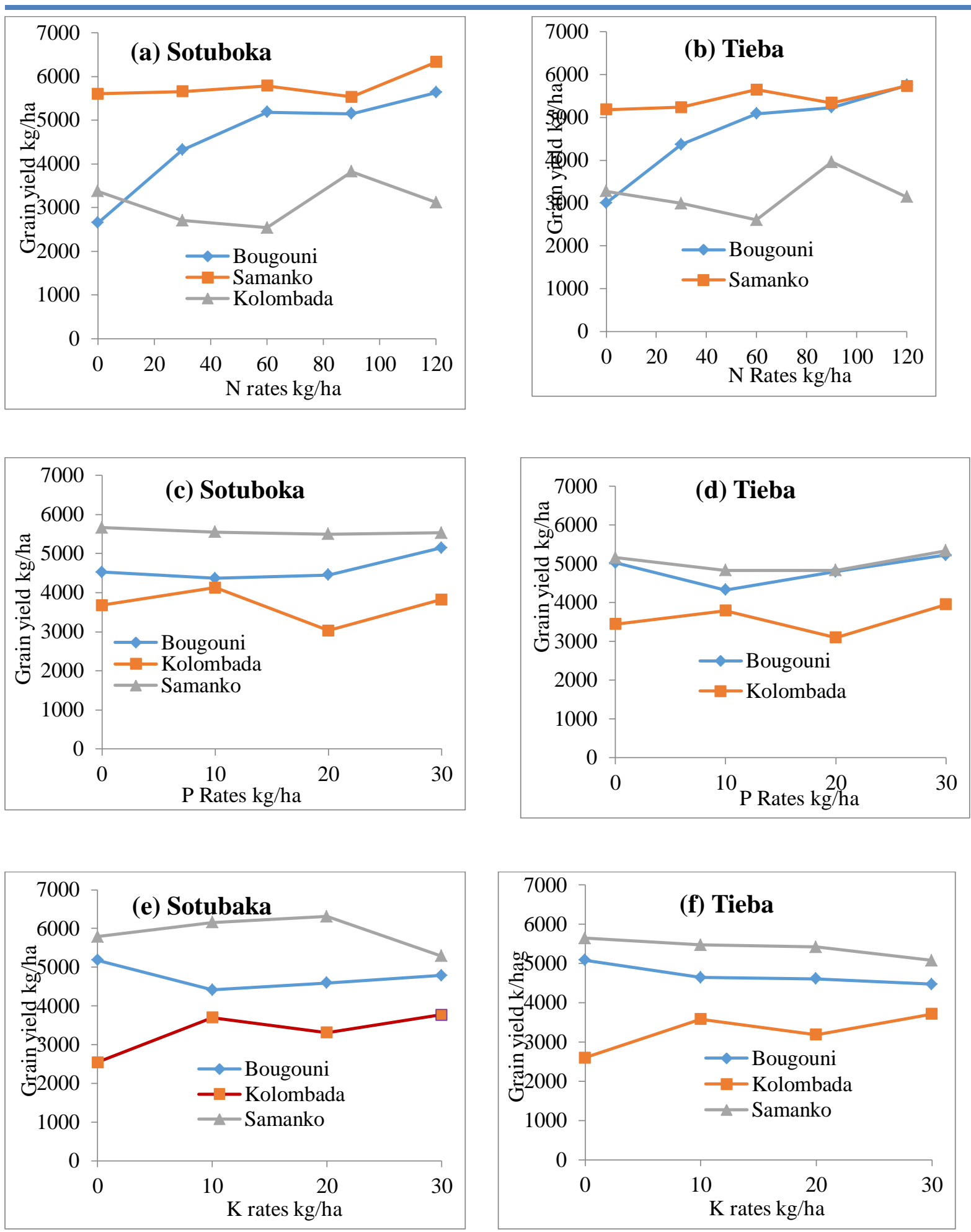

Figure 3: Varietal differences in response to $\mathrm{N}$ (when $\mathrm{P}$ is fixed at $30 \mathrm{~kg} / \mathrm{ha}$ ), $\mathrm{P}$ (when $\mathrm{N}$ is fixed at $90 \mathrm{~kg} / \mathrm{ha}$ ), and $\mathrm{K}$ (when NP is fixed at 60 and $\mathrm{P}$ at $30 \mathrm{~kg} / \mathrm{ha}$ ) averaged across two years

The asymptotic regression for response to $\mathrm{P}$ did not fit the data well for both Sotubaka and Tieba as indicated by very large standards errors of most of the coefficients (Tables 3). Similar problems were also observed for yield response to $\mathrm{K}$ (Table 3 ).

\subsection{Nutrient use efficiency (NUE)}

3.3.1. Agronomic Efficiency of $N(A E N)$

AEN ( $\mathrm{kg}$ increase in yield $/ \mathrm{kg}$ of applied $\mathrm{N}$ ) did not significantly vary with treatment but it varied with variety at Bougouni and Samanko (Table 4). The 
Optimizing Inorganic Fertilizers Use for Sustainable Intensification of Rain-Fed Maize in Three Agro-Ecological Zones of Mali

highest AEP $(36.6 \mathrm{~kg} / \mathrm{kg})$ at Bougouni was found in $30 \mathrm{~kg} / \mathrm{ha} \mathrm{N}+40 \mathrm{~kg} / \mathrm{ha} \mathrm{P}$ (Treatment 10). At Samanko the highest AEN was recorded in $30 \mathrm{~kg} / \mathrm{ha} \mathrm{N}+30$ $\mathrm{kg} / \mathrm{ha} \mathrm{P}$ (Treatment 11). AEP was negative in most cases at Kolombada. At Bougouni in 2014, the maximum AEN for Sotubaka was $82 \mathrm{~kg}$ increase in yield per $\mathrm{kg}$ of applied $\mathrm{N}\left(\mathrm{T}_{10}\right)$ where as in 2015 it was $26 \mathrm{~kg}\left(\mathrm{~T}_{11}\right)$. For Tieba the same trend was observed with a maximum AEN of $38 \mathrm{~kg}$ in 2014 $\left(\mathrm{T}_{6}\right)$ compared to $19 \mathrm{~kg}$ in $2015\left(\mathrm{~T}_{10}\right)$. Between the two genetic materials, the efficiency was superior for Sotubaka compared to that of Tieba (data not shown). At Kolombada in both 2014 and 2015, AEN did not significantly vary with varieties; both genetic materials had negative value of AEN (table not shown).

At Samanko, the maximum AEN for Sotubaka was $63 \mathrm{~kg} / \mathrm{kg}$ of applied $\mathrm{N}\left(\mathrm{T}_{11}\right)$ where as in 2015 it was $19 \mathrm{~kg}\left(\mathrm{~T}_{15}\right)$ in 2014 . For Tieba the same trend was observed with a maximum agronomic efficiency of $42 \mathrm{~kg}$ in $2014\left(\mathrm{~T}_{11}\right)$ compared to $93 \mathrm{~kg}$ in $2015\left(\mathrm{~T}_{10}\right)$. Between the two genetic materials, AEN was superior for Tieba compared to Sotubaka (tables not shown).

\subsubsection{Agronomic Efficiency of $P$}

AEP significantly varied with year, treatment and variety at Bougouni, Kolombada but not at Samanko. The highest AEP values were found at all three sites with a combination of $90 \mathrm{~kg} / \mathrm{ha} \mathrm{N}+10 \mathrm{~kg} / \mathrm{ha} \mathrm{P}$ was applied (Treatments 7) (table 4). AEP was negative in most cases at Kolombada.

At Bougouni, in 2014, the highest AEP was highest for Sotubaka and Tieba with 270 and $150 \mathrm{~kg} / \mathrm{kg}$ both recorded in $90 \mathrm{~kg} / \mathrm{ha} \mathrm{N}+10 \mathrm{~kg} / \mathrm{ha} \mathrm{P}$ (Treatment 7). In 2015 AEP was highest $(51 \mathrm{~kg} / \mathrm{kg})$ in $\mathrm{T}_{12}$ for Sotubaka and $20 \mathrm{~kg} / \mathrm{kg}$ in $\mathrm{T}_{13}$ for Tieba (data not shown). At Kolombada, in 2014, the maximum agronomic efficiency for Sotubaka was $20 \mathrm{~kg} / \mathrm{kg}$ and $150 \mathrm{~kg} / \mathrm{kg}$ in 2015 both recorded in $90 \mathrm{~kg} / \mathrm{ha} \mathrm{N}+10$ $\mathrm{kg} / \mathrm{ha} \mathrm{P}$ (Treatment 7). At Samanko, in 2014, the highest AEP for Sotubaka was $132 \mathrm{~kg} / \mathrm{kg}$ where as in 2015 it was $41 \mathrm{~kg} / \mathrm{kg}$ both recorded in $90 \mathrm{~kg} / \mathrm{ha} \mathrm{N}+$ $10 \mathrm{~kg} / \mathrm{ha} \mathrm{P}$ (Treatment 7). For Tieba the same trend was observed with a maximum agronomic efficiency of $83 \mathrm{~kg} / \mathrm{kg}$ in 2014 compared to $142 \mathrm{~kg} / \mathrm{kg}$ in 2015 both recorded in $90 \mathrm{~kg} / \mathrm{ha} \mathrm{N}+10 \mathrm{~kg} / \mathrm{ha} \mathrm{P}$ (Treatment 7).

Table 4: Variation in agronomic efficiency of $\mathrm{N}$ (AEN in $\mathrm{kg}$ increase/ $\mathrm{kg}$ of applied $\mathrm{N}$ ) and $\mathrm{P}$ (AEP in $\mathrm{kg} / \mathrm{ha}$ of applied $\mathrm{P}$ ) with treatment and site

\begin{tabular}{|c|c|c|c|c|c|c|c|}
\hline \multirow[b]{2}{*}{ Code } & \multirow[b]{2}{*}{ Treatment } & \multicolumn{3}{|c|}{ Agronomic efficiency of N (AEN) } & \multicolumn{3}{|c|}{ Agronomic efficiency of P (AEP) } \\
\hline & & Bougouni & Koulombada & Samanko & Bougouni & Koulombada & Samanko \\
\hline 2 & NOP10K0 & NA & NA & NA & 5.4 & -15.9 & 55 \\
\hline 3 & NOP20K0 & NA & NA & NA & -18.4 & -36 & 30.1 \\
\hline 4 & NOP30K0 & NA & NA & NA & -10.1 & -15.1 & 45 \\
\hline 5 & NOP40K0 & NA & NA & NA & -4.5 & -37.8 & 11 \\
\hline 6 & N90P0K0 & 13.4 & -9.6 & 13.4 & NA & NA & NA \\
\hline 7 & N90P10K0 & 5.7 & -5.9 & 9.9 & 105.5 & 47.0 & 100.0 \\
\hline 8 & N90P20K0 & 11.0 & -13.5 & 9.9 & 49.1 & -12.3 & 54.3 \\
\hline 9 & N90P30K0 & 15.6 & -4.9 & 15.5 & 47.2 & -4.7 & 46.7 \\
\hline 10 & N30P40K0 & 36.6 & -6.6 & 34.3 & 21.3 & -186.0 & 25.8 \\
\hline 11 & N30P30K0 & 18.6 & -22.4 & 43.3 & 18.5 & -22.4 & 43.3 \\
\hline 12 & N60P30K0 & 21.0 & -20.9 & 28.3 & 42.2 & -32.3 & 56.9 \\
\hline 13 & N120P30K0 & 16.0 & -9.7 & 14.7 & 34.1 & -15.3 & $67.0^{\mathrm{a}}$ \\
\hline 14 & N60P30K10 & 18.3 & -12.1 & 22.2 & 37.0 & 4.7 & 44.6 \\
\hline 15 & N60P30K20 & 13.2 & -18.9 & 24.7 & 26.7 & -15.4 & 49.5 \\
\hline 16 & N60P30K30 & 11.0 & -10.3 & 18.9 & 22.0 & -5.4 & 38.1 \\
\hline 17 & Diagnostic & 21.2 & -4.7 & 15.5 & 63.7 & 7.7 & 47.1 \\
\hline \multirow[t]{4}{*}{18} & N200P80K0 & 9.4 & -2.2 & 11.0 & 23.6 & -6.0 & 27.9 \\
\hline & P year & $<0.001$ & $<0.010$ & 0.415 & $<0.001$ & 0.003 & 0.544 \\
\hline & P treatment & 0.785 & 0.762 & 0.101 & 0.004 & 0.006 & 0.454 \\
\hline & $P$ variety & 0.049 & 0.474 & 0.003 & 0.019 & $<0.001$ & 0.007 \\
\hline
\end{tabular}


Optimizing Inorganic Fertilizers Use for Sustainable Intensification of Rain-Fed Maize in Three Agro-Ecological Zones of Mali

\subsection{Rain use efficiencies (RUE)}

The rain use efficiency significantly varied with year at all the three sites (Table 5). Variety effect was significant only at Samanko at $\mathrm{P}<0.05$. The efficiency varies from 2.5 to 4.6 at Bougouni, 3.3 to 6.3 at Kolombada and 4.3 to 7 at Samanko (table 5). In 2014 at Bougouni, the highest RUE for Sotubaka was 5.33 where as in 2015 it was 3.7 both recorded in $\mathrm{T}_{13}$. For Tieba the same trend was observed with a maximum rain use efficiency of 6 in $T_{6}$ in 2014 compared to 3.9 in $\mathrm{T}_{13}$ in 2015 . For Tieba the same trend was observed with the highest RUE of 7 recorded in $\mathrm{T}_{4}$ in 20146.8 recorded in $\mathrm{T}_{9}$ in 2015 . At Samanko, in 2014, the highest RUE for Sotubaka was 6 in $T_{8}$ where as in 2015 it was 7.33. For Tieba the same trend was observed with maximum rain use efficiency of 5.9 in $\mathrm{T}_{13}$ ) in 2014 and 8.4 in $\mathrm{T}_{12}$ in 2015. Across sites, Tieba had superior RUE compared to Sotubaka (data not shown).

Table 5: Variation in rain use efficiency (RUE) and value cost ratio (VCR) due to applied N across year and site

\begin{tabular}{|c|c|c|c|c|c|c|c|}
\hline \multirow[b]{2}{*}{ Code } & \multirow[b]{2}{*}{ Treatment } & \multicolumn{3}{|c|}{ Rain use efficiency (RUE) } & \multicolumn{3}{|c|}{ Value cost ratio (VCR) } \\
\hline & & Bougouni & Koulombada & Samanko & Bougouni & Koulombada & Samanko \\
\hline 1 & NOPOK0 & 2.5 & 3.3 & 4.3 & NA & NA & NA \\
\hline 2 & NOP10K0 & 2.5 & 5.2 & 4.8 & -3.4 & -11.5 & 2.2 \\
\hline 3 & NOP20K0 & 2.4 & 4.8 & 4.8 & -2.1 & -6.7 & 1.0 \\
\hline 4 & NOP30K0 & 2.5 & 4.2 & 5.8 & -1.1 & -1.6 & 2.8 \\
\hline 5 & NOP40K0 & 2.8 & 5.0 & 4.9 & -0.1 & -3.3 & 0.7 \\
\hline 6 & N90P0K0 & 4.0 & 5.9 & 5.9 & NA & NA & NA \\
\hline 7 & N90P10K0 & 3.5 & 5.1 & 5.5 & 1.6 & -0.8 & 1.5 \\
\hline 8 & N90P20K0 & 3.8 & 6.0 & 5.5 & 0.7 & -0.4 & 1.0 \\
\hline 9 & N90P30K0 & 4.2 & 6.2 & 6.1 & 1.1 & -0.7 & 0.8 \\
\hline 10 & N30P40K0 & 3.7 & 6.1 & 5.7 & 1.1 & 0.0 & 1.2 \\
\hline 11 & N30P30K0 & 3.4 & 3.9 & 5.9 & 1.2 & -0.9 & 1.2 \\
\hline 12 & N60P30K0 & 4.0 & 3.2 & 6.4 & 0.9 & -1.2 & 1.7 \\
\hline 13 & N120P30K0 & 4.6 & 5.6 & 6.5 & 1.3 & -1.2 & 1.6 \\
\hline 14 & N60P30K10 & 3.7 & 3.2 & 6.3 & 1.4 & -0.5 & 1.2 \\
\hline 15 & N60P30K20 & 3.7 & 5.6 & 6.2 & 1.1 & -0.3 & 1.3 \\
\hline 16 & N60P30K30 & 3.5 & 6.1 & 5.8 & 0.8 & -0.5 & 1.4 \\
\hline 17 & Diagnostic & 4.5 & 4.9 & 6.1 & 0.7 & -0.3 & 0.9 \\
\hline \multirow[t]{4}{*}{18} & N200P80K0 & 4.6 & 6.3 & 7.0 & 1.3 & -0.1 & 1.0 \\
\hline & P year & $<0.001$ & $<0.001$ & $<0.001$ & $<0.001$ & 0.364 & 0.902 \\
\hline & $P$ treatment & $<0.001$ & $<0.001$ & $<0.001$ & 0.001 & $<0.001$ & 0.986 \\
\hline & $P$ variety & 0.638 & 0.551 & 0.002 & 0.066 & 0.509 & 0.006 \\
\hline
\end{tabular}

\subsection{Returns to investment in fertilizer use (value cost ratio)}

The value cost ratio (VCR) significantly varied with treatment and year at Bougouni (Table 5), not at Samanko. VCR also significantly varied with treatment at Kolombada. However, at all sites VCR was smaller than the cut-off point of 2 to be profitable except in treatments 2 and 4 at Samanko. VCR differed among the varieties only at Samanko. Positive values of VCR were observed at Bougouni in treatments 7-18; the highest being in Treatment 7 (90 kg/ha N and $10 \mathrm{~kg} / \mathrm{ha} \mathrm{P).} \mathrm{At} \mathrm{Kolombada,} \mathrm{where}$ rainfall was below its historic average VCR had negative values for all the treatments. On the other hand, VCR values were all positive for all the treatments at Samanko, the highest being in Treatment 4 (30 kg/ha P), (Table 5).

\section{Discussion}

The results of the study revealed differences in responses to treatments across the three agroecological zones. Response to treatments was higher at Samanko (Upper Bani-Niger) and Bougouni (Manding plateau) compared to Kolombada. Both Sotubaka and Tieba performed better at Bougouni where rainfall received during the growing season was high and well distributed. On the other hand, yields were very low at Koulombada where rainfall received during the growing season was very low (567-674 $\mathrm{mm})$ relative to its historic average of 800 $1000 \mathrm{~mm}$. This is consistent with Traoré (2010) who reported that maize production in Mali is largely dependent on the low quantity and poor distribution of rainfall. The yield the responses of the varieties was higher in the diagnostic treatment and the highest NPK rates that are not economically profitable for 
producers. The synergic effect of $\mathrm{N}$ and $\mathrm{P}$ was more remarkable on yield of the maize varieties when $\mathrm{P}$ was applied at fixed rate of $30 \mathrm{~kg} / \mathrm{ha}$. This is in agreement with Traoré (2010) and FAO (1995) who indicated that maize production is confronted with the declining in soil fertility due to overexploitation and the gradual depletion of the same soil in fertilizer elements nitrogen, phosphorus, potassium and organic matter. This was further supported by Niang et al. (2000) who reported that Malian farmers annually invest $40 \%$ of their income in soil fertilization. The yields obtained with the tested fertilizers rates are superior to those of the control. These results are in agreement with the idea forwarded by Wortmann (2014) that the yield of crops including maize can be increased 2-3 times with a moderate level of fertilization and this can give producers significant monetary income. This study has shown that the maximum increase in yield due to $\mathrm{kg}$ of applied $\mathrm{N}$ was highest with $30 \mathrm{~kg} / \mathrm{ha} \mathrm{N}$ and $40 \mathrm{~kg} \mathrm{P}$ ) at Bougouni and Samanko. The maximum increase in yield due to $\mathrm{kg}$ of applied $\mathrm{P}$ was recorded at $90 \mathrm{~kg} / \mathrm{ha} \mathrm{N}$ and $10 \mathrm{~kg} / \mathrm{ha} \mathrm{P}$ in Bougouni site. The negative values of AEN and AEP at Kolombada indicate that applied $\mathrm{N}$ and $\mathrm{P}$ were not utilized efficiently. The maximum yield response of the maize varieties to $\mathrm{N}$ when $\mathrm{P}$ was applied at a fixed rate of $30 \mathrm{~kg} / \mathrm{ha}$ was achieved at $\mathrm{N}$ rate of 120 $\mathrm{kg} / \mathrm{ha}$ at Bougouni and Samanko and Their maximum response to $\mathrm{P}$ (holding $\mathrm{N}$ at $90 \mathrm{~kg} / \mathrm{ha}$ ) had however a large standards errors which are deemed unreliable: the coefficients of the asymptotic response were not successfully estimated because the maximum $\mathrm{N}$ applied (120 kg/ha) and the maximum $\mathrm{P}$ applied 30 $\mathrm{kg} / \mathrm{ha}$ were too low for the maize varieties to reach their asymptotic yield for Bougouni and Samanko. The maximum increase in yield due to $\mathrm{kg}$ of applied $\mathrm{N}$ was highest with $30 \mathrm{~kg} / \mathrm{ha} \mathrm{N}$ and $40 \mathrm{~kg} / \mathrm{ha} \mathrm{P}$ at Bougouni and Samanko. This means $\mathrm{P}$ rate should have been increased to $40 \mathrm{~kg}$ to correctly estimate the asymptotic response coefficients. According to Ladha et al. (2005) the agronomic efficiency nutrients is an integrated index of nutrient recovery efficiency and physiological use efficiency. When the nutrient $\mathrm{N}, \mathrm{P}$ or $\mathrm{K}$ is applied to the crop, its effect is known through the increase in yield and its uptake by the plant is illustrated by the recovery quantity of $\mathrm{N}, \mathrm{P}$ or $\mathrm{K}$ in grains or in Stover. This phenomenon is mainly explained by the harvest index which is an indication of the nutrient distribution between the grains and plant Stover. A good index or good agronomic efficiency would be a high increase in yield per $\mathrm{kg}$ of applied nutrient. The highest control yield observed at Samanko for both genetic materials could be explained by soil irregularity and the rich nature of Limon-sandy soil of $45 \%$ and $42 \%$ respectively and soil $\mathrm{P}$ total content of $210.10 \mathrm{ppm}$, LABOSEP/IER (2013)
Examination of RUE values indicate that the efficiency with which the rainfall was used was relatively higher at Samanko than the other two sites, because the rainfall distribution was relatively better compared to Bougouni and Kolombada. The profitability of fertilizer use assessed using VCR indicate that applying any of the treatments at Kolombada and Bougouni will not be profitable because VCR was less than the cut-off point of 2 . However, applying just $30 \mathrm{~kg} / \mathrm{ha} \mathrm{P}$ was profitable at Samanko. The AEN, AEP and VCR were all negative on the Kolombada site probably this site had very low rainfall. This combined with the very low organic matter content of the soil could have led to less efficient use of applied nutrients. Application of high doses of fertilizer on sites with low rainfall may result in loss of nutrients and may contribute to environmental pollution

\section{Conclusion}

In conclusion the maize yield response to NPK was higher at Samanko and Bougouni due adequate rains that resulted in better nutrients and rain use efficiency. In terms of yield response, the best combinations across the three agro-ecological zones were the application of $\mathrm{N}$ at the rate of $120 \mathrm{~kg} / \mathrm{ha}$ together with $\mathrm{P}$ applied at the rate of $30 \mathrm{~kg} / \mathrm{ha}$. However, the value cost ration was highest when 90 $\mathrm{kg} / \mathrm{ha} \mathrm{N}$ and $10 \mathrm{~kg} / \mathrm{ha} \mathrm{P}$ were applied at Bougouni and when $30 \mathrm{~kg} / \mathrm{ha} \mathrm{P}$ was applied at Samanko. On the other hand, VCR values were negative in all treatments at Kolombada where rainfall received during the two cropping seasons was lower than the historical average. It is thus concluded that increased rates of NPK could be unprofitable on sites or seasons with low rainfall. These results need to be verified on farmers' fields before recommending them to farmers.

\section{Acknowledgement}

The authors are grateful to the following institutions that have assisted technically and financially in this work: Mali Institute of Rural Economy (IER), the alliance for green revolution (AGRA), CAB International Africa in Nairobi, Kenya and the University of Nebraska-Lincoln in the United States of America. They are also grateful to Dr. Gudeta W. Sileshi for his efforts of editing the manuscript; the laboratory and field technicians, $\mathrm{Mr}$ Makono Coulibaly, Mr Sidaty Mahamane, Mr Mohamed Samba Touré and Mr Adama Niaré who contributed to the laboratory work and the conduct of the field experiments.

\section{References}

1. AGRA. (2013) Africa Agriculture Status Report. Focus on staple crops. AGRA. http://wwww.agraalliance.org/download/533977a50dbc7/ 
2. Bai, Z.G., Dent, D.L., Olsson, L., Schaepman, M.E. (2008) Proxy global assessment of land degradation. Soil Use Manage. 24: 223-234.

3. Chilimba, A.D., Young, S.D., Black, C.R., Meacham, M.C., Lammel, J., Broadley, M.R. (2012) Agronomic biofortification of maize with selenium (Se) in Malawi. Field Crops Research 125: 118-128.

4. CIMMYT (2013) The Drought Tolerant Maize for Africa project. DTMA Brief, September http://dtma.cimmyt.org/index.php/about/background

5. CNFA. (2010). Répertoire des agro-dealers du Mali. 2000 adresse à travers tout le pays. 190 pages.

6. DNA. (2012). Rapport annuel de la Direction Nationale de l'Agriculture du Mali.

7. FAOSTST. (2015) Organisation pour l'alimentation et l'agriculture des nations unies, division de la statistique. Programme de l'alimentation et l'agriculture des nations.

8. FAO. (1995) Integrated plant nutrition systems, by R. Dudal \& R. N. Roy. eds. FAO Fertilizer and plant nutrition Bulletin $\mathrm{N}^{\circ} 12$ Rome. In FAO fertilizer and plant nutrition Bulletin $\mathrm{N}^{\circ}$ 13: Use of phosphate rocks for sustainable agriculture, $2 \mathrm{p}$.

9. Hatfield, J.L., Sauer, T.J., Prueger, J.H., (2001) Managing soils to achieve greater water use efficiency: A Review. Agron. J. 93, 271-280.

10. Grassini, P., Eskridge, K.M., Cassman, K.G. (2013) Distinguishing between yield advances and yield plateau in historical crop production trends. Nature Communications 4: 2918 |DOI: 10.1038/ncomms3918.

11. Kihara, J., Huising, J., Nziguheba, G., Waswa, B.S., Njoroge, S., Kabambe, V., Iwuafor E., Kibunja, C., Esilaba, A.O. \& Coulibaly, A. (2016) Maize response to macronutrients and potential for profitability in sub-Saharan Africa. Nutrient Cycling in Agroecosystems, 105, 171-18.

12. LABOSEP/IER. (2013). $\mathrm{N}^{\circ}$ SERIE: O-87, analyse de sol de la sous-station de Samanko; BP: 262, TEL: 44384975 (2013), Sotuba, Bamako.

13. Ladha, J.K., Pathak, H., Krupnik, T.J., Six, J. \& van Kessel, C. (2005). Efficiency of fertilizer nitrogen in cereal production: retrospect and prospects. Advances in Agronomy, 87, 85-156.

14. Niang A., Yossi H., Tabo R., Akintayo I. (2000) Evaluation of various shrubs for short duration improved fallow for soil fertility improvement and crop yield enhancement in the Sahel an region (document de projet. $15 \mathrm{p}$

15. Pieri C. (1990). Industries des engrais phosphatés et développement de la fertilisation en Afrique Agronomie tropicale. 43 (4): 261-277.

16. PIRT, (1986). Zonage agro-écologique du Mali- Tome 3, Institut National de Recherche Zootechnique, Forestière et Hydro biologique, Sotuba-Mali, $481 \mathrm{p}$.

17. Ray, D.K., Mueller, N.D., West, P.C., and Foley, J.A. (2013) Yield trends are insufficient to double global crop production by 2050. PLoS ONE 8(6): e66428. https://doi.org/10.1371/journal.pone.0066428.

18. SAFGRAD (Semi-arid Food Grain Research And Development), (1985) Rapports annuels. Institut d'Economie Rurale (IER), Mali.

19. Sanchez, P. (2010) Tripling yields in tropical Africa. Nature Geoscience3, 299-300.

20. Sileshi GW, Akinnifesi FK, Ajayi OC, Muys B. (2011) Integration of legume trees in maize-based cropping systems improves rainfall use efficiency and crop yield stability. Agricultural Water Management 98: 1364-1372.

21. Soumaré M. (2014) Contribution à la prévision de l'aire de diffusion de variétés de sorgho au Mali. Couplage entre modèle de croissance des cultures et système d'information, Mémoire de DEA en géographie Université de Paris $\mathrm{X}$, Institut National Agronomique de Paris-Grignon, 92p.

22. Tidemann-Andersen, I., Acham, H., Maage, A., Malde, M.K (2011) Iron and zinc content of selected foods in the diet of schoolchildren in Kumi district, east of Uganda: a crosssectional study. Nutrition Journal 10 : 81-92.

23. Traoré L. (2010) Effet de l'utilisation de microorganismes dissolvant le phosphate naturel de Tilemsi sur la croissance et la production du maïs (thèse de Doctorat, Université de Bamako, 148 pages).

24. Traoré L. 1986 Expérience en matière d'essais dans les champs des paysans: Etude de cas au Mali, IER/OUA/SAFGRAD, Bamako, Mali (International Drought Symposium, Nairobi, Kenya 19-23 rd. May 1986, pages 633649).

25. Wortmann. (2014). Protocole d'expérimentation de l'Optimisation des recommandations d'engrais en Afrique. 